\title{
ФАКТОРИ РИЗИКУ ВИНИКНЕННЯ ІНТРАОПЕРАЦІЙНИХ ГЕМОРАГІЧНИХ УСКЛАДНЕНЬ ПРИ МІНІ-ІНВАЗИВНОМУ ХІРУРГІЧНОМУ ЛІКУВАННІ ПРОЛІФЕРАТИВНОї ДІАБЕТИЧНОЇ РЕТИНОПАТІЇ
}

\author{
А. М. Рубан \\ Національна медична академія післядипломної освіти імені П. Л. Шупика
}

\begin{abstract}
Проведено ретроспективне дослідження 80 операцій (вітректомій 23/25G) у неселективній когорті 80 пацієнтів (80 очей) з проліферативною діабетичною ретинопатією. Вивчено вплив інтраопераційних ускладнень на результат хірургічного лікування та виявлення фракторів ризику виникнення профузного крововиливу сітківки при виконанні вітректомії 23/2SG. Показано, що ряд клінічних показників підвищує ризик незадовільного результату операцій або окремих ускладнень. Так, при профузних крововиливах ризик незадовільного результату вище в 3,5 раза. При тривалості операції більше однієї години ризик виникнення крововиливів зростає у 5 разів.
\end{abstract}

Ключові слова: проліферативна діабетична ретинопатія, вітректомія 23/25G, інтраопераційні ускладнення, профузний крововилив, фрактори ризику.

\section{ФАКТОРЫ РИСКА ВОЗНИКНОВЕНИЯ ИНТРАОПЕРАЦИОННЫХ ГЕМОРРАГИЧЕСКИХ ОСЛОЖНЕНИЙ ПРИ МИНИ-ИНВАЗИВНОМ ХИРУРГИЧЕСКОМ ЛЕЧЕНИИ ПРОЛИФЕРАТИВНОЙ ДИАБЕТИЧЕСКОЙ РЕТИНОПАТИИ}

\begin{abstract}
А. Н. Рубан
Национальная медицинская академия последипломного образования имени П. Л. Шупика

Проведено ретроспективное исследование 80 операций (витрэктомия 23/25G) в неселективной когорте 80 пациентов (80 глаз) с пролиферативной диабетической ретинопатией. Изучено влияние интраоперационных осложнений на результат хирургического лечения и выявления факторов риска возникновения профузного кровоизлияния сетчатки при выполнении витрэктомии 23/25G. Показано, что ряд клинических показателей повышает риск неудовлетворительного результата операций или отдельных осложнений. Так, при профузных кровоизлияниях риск неудовлетворительного результата выше в 3,5 раза. При продолжительности операции более одного часа риск возникновения кровоизлияний возрастает в 5 раз.
\end{abstract}

Ключевые слова: пролиферативная диабетическая ретинопатия, витрэктомия 23/25G, интраоперационные осложнения, профузное кровоизлияние, фракторы риска.

\section{PREDICTIVE CLINICAL FEATURES OF HEMORRHAGES COMPLICATIONS IN MINIINVASIVE DIABETIC VITRECTOMY}

\author{
A. M. Ruban \\ National Medical Academy of Postgraduate Education by P. L. Shupyk
}

\begin{abstract}
The article presents the risk factors for hemorrhages complications in patients with miniinvasive diabetic vitrectomy. This was a retrospective study of 80 eyes (80 patients) who underwent combined sutureless vitrectomy 23/25G for the complications of proliferative diabetic retinopathy. The main outcome measures were visual outcomes and surgical complications. Indications for the surgery were vitreous hemorrhage and tractional retinal detachment. The main predictive clinical features of hemorrhages complications in diabetic vitrectomy were: exicision of fibrovascular membranes $(\phi=0,49, p<0,001)$, hypoglycemia $(R R=4,52$, $95 \% \mathrm{Cl}: 2,28-8,97),(\phi=0,48, p<0,001)$, operative time (>1 hour) (RRP $=4,68,95 \% \mathrm{Cl}: 2,80-7,23)$, combine retinal detachment $(\mathrm{RR}=4,52,95 \% \mathrm{Cl}: 1,18-17,3)$.
\end{abstract}

Key words: proliferative diabetic retinopathy, vitrectomy $23 / 25 \mathrm{G}$, intraoperative complications, haemovragia profusa, predictive factors. 
Вступ. Згідно з даними ВООЗ, проблема цукрового діабету (ЦЦ) в світі на сучасному етапі розцінюється як глобальна епідемія. Так, у 2003 році загальна кількість хворих на цукровий діабет у світі становила близько 189 млн чоловік. Щорічно ця цифра збільшується на 5-7 \% [1]. За прогнозами експертів у 2025 році їх кількість перевищить 324 млн людей. В Україні офіційно зареєстровано близько 1,5 млн хворих на цукровий діабет, проте вважають, що справжня захворюваність є значно більшою. Головною причиною інвалідизації хворих є діабетична проліферативна ретинопатія (ЦІ ІР) - ускладнення ЦЦ, що призводить до загибелі сітківки, зорового нерва та стійкої й незворотної сліпоти. На їі частку припадає 80-90 \% усієї інвалідності по зору, зумовленої цукровим діабетом [2]. Міні-інвазивна вітреоретинальна хірургія дозволяє стабілізувати та покращити зорові функції у 65-80 \% пацієнтів із ускладненнями проліферативної діабетичної ретинопатії. Разом $з$ тим, це не дозволило повністю уникнути появи тяжких інтра- та післяопераційних геморагічних ускладнень, що в свою чергу може призвести до незадовільного результату операції та важкої втрати зору пацієнтами [3].

Мета роботи - визначення факторів, що підвищують ймовірність виникнення геморагічних ускладнень при виконанні вітректомії $23 / 250$ у пацієнтів із ЦПР.

Матеріали та методи. Проведено ретроспективне дослідження 80 операцій (вітректомій) у неселективній когорті 80 пацієнтів ( 80 очей) з ЦПР. Загальну групу склали пацієнти з вітреальним крововиливом $\mathrm{i}$ тракційним відшаруванням сітківки. В групу увійшли 53 (66,2\%) пацієнти 31 типом цукрового діабету, 27 (33,8 \%) пацієнтів з 2 типом цукрового діабету, тривалість діабету $>15$ років відмічена у 74 (94,9\%) пацієнтів, та $<15$ років у $6(5,1 \%)$. Вік пацієнтів становив від 17 до 71 року, серед яких 29 пацієнтів (36,3\%) були молодше 50 років і 51 пацієнт $(63,7 \%)$ старше 50 років. Чоловіків було 45 (56,3\%), жінок $35(43,8 \%)$.
Усі отримані результати статистично вірогідні $(\mathrm{p}<0,01)$.

Перед операцією проводили: визначення гостроти зору, біомікроскопію, офтальмоскопію, статичну та динамічну периметрію, тонометрію, ультразвукове сканування (при неможливості огляду очного дна), оптичну когерентну томографію (для діагностики макулярного набряку, розриву, вітреомакулярної тракції). Гостроту зору визначали за таблицею Сівцева - Головіна. Операції виконувались одним хірургом (PAM) на субтеноновій анестезії за класичною методою 3-портової вітректомії з використанням інструментів калібру $23 / 25 \mathrm{G}$ на хірургічному комплексі «Stellaris PC» (Bausch\&Lomb). Видаляли центральне склоподібне тіло, проводили усунення передньозадніх тракцій та максимально повне видалення фіброваскулярних мембран та задньої гіалоїдної мембрани технікою деламінації або сегментації. При необхідності проводили панретинальну ендолазеркоагуляцію. Для візуалізації очного дна використовували ширококутову систему Resight (Carl Zeiss Meditec, Germany). При необхідності виконували факоемульсифікацію кришталика через рогівковий розтин 1,8 мм та імплантували IOЛ (Bausch\&Lomb). При виконанні бімануальної техніки використовували додаткове освітлення PSG (Awh, Stellaris), P9G (chandelier, Synergetics). Силіконова або газова тампонада проводилась за визначенням хірурга. Критерії незадовільного анатомічного та функціонального результату операцій наведені нами раніше [4].

Результати та їх обговорення. Тридцять вісім (47 \%) з SO очей мали максимально кориговану гостроту зору (МКГЗ) <O, І на кінцевому огляді, що визначалось як незадовільний функціональний результат операції (несприятлива група), та 42 (52 \%) ока мали МКГЗ >0, I (сприятлива група).

Найбільш частими інтраопераційними ускладненнями в проведеному дослідженні були: преретинальні крововиливи на 53 очах (66 \%) та ятрогенні розриви сітківки на I3 очах (I6 \%). Вивчали зв'язок інтраопераційних ускладнень із результатом операції (табл. I).

Таблиця I . Вплив інтраопераційних ускладнень на результат вітректомії при ДПР

\begin{tabular}{|c|c|c|c|c|c|}
\hline \multirow{2}{*}{ Фактор ризику } & \multirow{2}{*}{ Xi-квадрат, x $^{2}$} & \multirow{2}{*}{ Сила зв'язку, <p } & \multirow{2}{*}{ Відносний ризик } & \multicolumn{2}{|c|}{$95 \%$ довірчий інтервал } \\
\hline & & & & нижній & верхній \\
\hline Ятрогенний розрив сітківки & 28,9 & 0,6 & 4,4 & 2,2 & 8,9 \\
\hline Профузний крововилив & 31,5 & 0,6 & 3,5 & 2,3 & 5,9 \\
\hline Ішемія сітківки & 19,5 & 0,5 & 2,8 & 1,9 & 4,0 \\
\hline
\end{tabular}

Виявлено, що у даної групи пацієнтів відмічається сильний зв'язок між наявністю профузного кровови- ливу $(\phi=0,6)$, ятрогенних розривів сітківки $(\phi=0,6)$ та незадовільним результатом операції. Також існує 
відносно сильний зв'язок незадовільного результату 3 ішемією сітківки $\mathbf{[ 巾}=0,5)$. Силу зв'язку інтерпретували відповідно до рекомендацій Rea \& Parker.

Ризик незадовільного результату при виникненні профузного крововиливу вище у 3,5 раза $(\mathrm{BP}=3,5$, 95 \% ДІ: 2,3-5,2), ніж при неускладненому перебігу операції $\left.\mathbf{I x}^{2}(\mathrm{i})=28,9, \mathbf{x}^{2}(1)=31,5\right)$.

Також виявлено, що ішемія сітківки, неадекватний мідріаз, субретинальна локалізація перфтордекаліну збільшують ризик незадовільного результату в 2,52,7 раза [5].

Виявлено взаємозв'язок між субкомпенсованим загальним станом пацієнта та виникненням профузного крововиливу $\left.\mathbf{I x}_{(1)}^{2}=6,1\right)$. Ризик виникнення геморагічних ускладнень у цієї групи пацієнтів вище в 1,7 раза $(\mathrm{BP}=1,7,95 \%$ ДІ: $1,0-2,8)$.

Визначено, що серед пацієнтів із гіпоглікемією ризик виникнення інтраопераційного профузного крововиливу вище у 4,5 раза, (BР=4,5, 95 \% ДІ: 2,3-9,0) ніж серед тих, хто має компенсований рівень глюкози крові $\left.\mathbf{X}^{2} @ \mathbf{\jmath}=19,2\right)$. Інтерпретуючи отримані значення критеріїв [р можна сказати, що в існує відносно сильний зв'язок між гіпоглікемією та виникненням геморагічних ускладнень $\mathbf{[} \mathbf{p}=0,5)$.

Серед інтраопераційних факторів найбільший зв'язок спостерігається між видаленням фіброваскулярних мембран і виникненням профузного крововиливу $(\mathbf{I}=0,5)$.

При тривалості операції більше 1 години ризик виникнення крововиливу зростає у 5 разів (BP=4,7, $95 \%$ ДI: 2,8-7,2) і звичайно ж існує сильний зв'язок між операційним часом і появою ятрогенних розривів сітківки $\left.\mathbf{X}_{(1)}^{2}=36,2, \phi=0,7\right)$.
Наявність у пацієнта тракційно-регматогенного відшарування сітківки в 4,5 раза (BP=4,5, 95 \% ДІ: 1,2-17,3) збільшує ризик профузного крововиливу, а субмакулярна проліферація збільшує ризик даного ускладнення майже в 3 рази (BP=2,8, 95 \% ДI: 1,0-7,6).

Видалення фіброваскулярних мембран мономануальною технікою пов'язано з більшим ризиком виникнення геморагічних ускладнень (ВР=1,4, 95 \% ДІ: 1,2-1,7), що потребує більш широкого використання бімануальної техніки видалення діабетичних мембран [6].

Виникнення інтраопераційного крововиливу потребувало проведення гідростатичного гемостазу (підвищення висоти штатива з іригаційним розчином) або механічного гемостазу (механічний тиск на джерело крововиливу кінцевою частиною рефлюксного інструменту чи вітреотома). При неефективності даних заходів використовували бімануальна техніку 3 одночасним застосуванням екструзійної канюлі та ендокаутера або ендолазеркоагулятора. Слід зазначити, що отримані нами результати підтверджують дані багатьох дослідників про те, що попереднє проведення панретинальної лазерної фотокоагуляції та доопераційне інтравітреальне введення інгібіторів ендотеліального фактора росту (VEGF) дозволяє значно зменшити ризик виникнення тяжких геморагічних інтраопераційних ускладнень $[7,8]$.

Зазначимо, що хоча проведення вітреоретинальної операції не дозволяє повністю уникнути виникнення геморагічних ускладнень, частота їх може бути значно знижена за рахунок ретельного планування операції, визначення та усунення впливу несприятливих факторів і визначення індивідуально зорієнтованих методик хірургічного лікування хворих на ДПР (табл. 2).

Таблиця 2. Зв'язок факторів ризику з виникненням геморагічних ускладнень під час операції при ДПР

\begin{tabular}{|c|c|c|c|c|c|c|}
\hline \multirow{2}{*}{ Фактор ризику } & \multirow{2}{*}{ Ст.св. } & \multirow{2}{*}{$\begin{array}{c}\text { Хі-квадрат } \\
\chi^{2}\end{array}$} & \multirow{2}{*}{$\varphi / \mathrm{V}$} & \multirow{2}{*}{$\begin{array}{c}\text { Відносний } \\
\text { ризик }\end{array}$} & \multicolumn{2}{|c|}{$95 \%$ - довірчий інтервал } \\
\hline & & & & & нижній & верхній \\
\hline 1 & 2 & 3 & 4 & 5 & 6 & 7 \\
\hline \multicolumn{7}{|c|}{ Соматичний стан } \\
\hline Ниркова недостатність & 1 & 10,4 & 0,4 & 2,2 & 1,2 & 4,0 \\
\hline Гіпоглікемія & 1 & 19,2 & 0,5 & 4,5 & 2,3 & 9,0 \\
\hline Ацетонурія & 1 & 12,1 & 0,4 & 2,2 & 1,6 & 3,1 \\
\hline Глюкоза крові > 10 ммоль/л & 1 & 10,6 & 0,4 & 6,1 & 1,5 & 24,5 \\
\hline Набряки кінцівок & 1 & 14,4 & 0,4 & 5,1 & 1,9 & 13,7 \\
\hline Альбумінурія & 1 & 9,6 & 0,4 & 9,3 & 1,3 & 65,2 \\
\hline Глюкозурія & 1 & 17,5 & 0,5 & 4,2 & 2,3 & 8,0 \\
\hline Гемоглобін $<100$ г/л & 1 & 20,7 & 0,5 & 4,7 & 2,5 & 9,0 \\
\hline Гіпертонічна хвороба & 1 & 4,8 & 0,3 & 1,3 & 1,1 & 1,6 \\
\hline Субкомпенсований загальний стан & 1 & 6,1 & 0,2 & 1,7 & 1,0 & 2,8 \\
\hline Енцефалопатія & 1 & 6,1 & 0,3 & 3,1 & 1,1 & 8,2 \\
\hline Переміжна кульгавість & 1 & 3,9 & 0,2 & 2,1 & 2,0 & 4,2 \\
\hline
\end{tabular}


Продовження табл. 2

\begin{tabular}{|c|c|c|c|c|c|c|}
\hline 1 & 2 & 3 & 4 & 5 & 6 & 7 \\
\hline \multicolumn{7}{|c|}{ Особливості хірургії } \\
\hline $\begin{array}{l}\text { Видалення фіброваскулярних } \\
\text { мембран }\end{array}$ & 1 & 26,5 & 0,6 & 3,9 & 2,3 & 6,5 \\
\hline Гідростатичний гемостаз & 1 & 21,1 & 0,5 & 2,4 & 1,8 & 3,2 \\
\hline $\begin{array}{l}\text { Видалення периферії склоподібного } \\
\text { тіла }\end{array}$ & 1 & 9,2 & 0,3 & 4,9 & 1,6 & 15,1 \\
\hline Тривалість операції & 1 & 36,2 & 0,7 & 4,7 & 2,8 & 7,2 \\
\hline Мономануальна техніка хірургії & 1 & 7,7 & 0,3 & 1,4 & 1,2 & 1,7 \\
\hline $\begin{array}{l}\text { Видалення фіброваскулярних } \\
\text { мембран від ДЗН }\end{array}$ & 1 & 12,6 & 0,4 & 2,8 & 1,6 & 4,9 \\
\hline Ендотампонада повітрям & 1 & 13,0 & 0,4 & 1,9 & 1,4 & 2,5 \\
\hline $\begin{array}{l}\text { Тимчасова тампонада } \\
\text { перфтордекаліном }\end{array}$ & 1 & 23,3 & 0,5 & 2,8 & 1,9 & 4,1 \\
\hline Ендотампонада легким силіконом & 1 & 4,1 & 0,2 & 2,8 & 1,1 & 7,8 \\
\hline Ендотампонада важким силіконом & 1 & 8,1 & 0,3 & 7,1 & 1,5 & 33,5 \\
\hline \multicolumn{7}{|c|}{ Офтальмологічний статус } \\
\hline Загальне поле зору & 2 & 5,7 & $0,4^{*}$ & - & - & - \\
\hline Центральна скотома & 1 & 11,7 & 0,7 & 1,4 & 1,1 & 1,9 \\
\hline Медикаментозний мідріаз & 1 & 12,6 & 0,4 & 2,8 & 1,6 & 4,9 \\
\hline Тракщійне відшарування макули & 1 & 6,2 & 0,3 & 1,4 & 1,1 & 1,7 \\
\hline Премакулярний крововилив & 1 & 8,7 & 0,3 & 2,2 & 1,4 & 3,7 \\
\hline Суб̆макулярна проліферація & 1 & 4,0 & 0,2 & 2,8 & 1,0 & 7,6 \\
\hline $\begin{array}{l}\text { Попереднє введення інгібітора } \\
\text { VEGF }\end{array}$ & 1 & 6,0 & 0,3 & 1,3 & 1,0 & 1,5 \\
\hline Попередня лазерна коагуляція & 2 & 16,8 & $0,5^{*}$ & 2,6 & - & - \\
\hline Аферентний зіничний дефект & 1 & 5,2 & 0,3 & 2,0 & 1,1 & 3,6 \\
\hline Рубеоз райдужки & 1 & 4,8 & 0,3 & 2,5 & 1,1 & 5,6 \\
\hline $\begin{array}{l}\text { Tракційно-регматогенне } \\
\text { відшарування сітківки }\end{array}$ & 1 & 5,7 & 0,3 & 4,5 & 1,2 & 17,3 \\
\hline Опероване око - монокулюс & 1 & 14,0 & 0,4 & 3,5 & 1,9 & 7,6 \\
\hline
\end{tabular}

Примітка. * для багатопільних таблиць застосовується критерій V Крамера.

Висновки. I. Визначення сили впливу інтраопераційних ускладнень на результат хірургічного лікування та виявлення факторів ризику виникнення профузного крововиливу сітківки при виконанні вітрекгомії 23/ $25 \mathrm{G}$ у пацієнтів 3 ДПР надає можливість створення індивідуальної схеми прогнозування клінічного перебігу та результатів хірургічного лікування.

\section{Література}

1. Риков С. О. Сліпота та слабкозорість. Шляхи профілактики в Україні / С. О. Риков. - К., 2011. - 268 с.

2. Oshima Y. Surgical outcomes of 25-gauge transconjunctival vitrectomy combined with cataract surgery for vitreoretinal diseases / Y. Oshima, M. Ohji, Y. Tano // Ann. Acad. Med. Singapore. - 2006. - № 35. - Р. 175-180.

3. Рубан А. М. Результати комбінованої $23 \mathrm{G}$ вітректомії 3 факоемульсифікацією та імплантацією ІОЛ у пацієнтів на проліферативну діабетичну ретинопатію / А. М. Рубан // Офтальмологічний журнал. - 2013. - №№ 2. - С. 36-42.
2. Подальше вивчення факторів ризику та розроблення індивідуальних заходів профілактики виникнення ускладнень дозволить значно підвищити ефективність хірургічного лікування та реабілітації хворих на ДПР.

4. Риков С. О. Фактори ризику в прогнозуванні виходу хірургічного лікування проліферативної діабетичної ретинопатії / С. О. Риков, А. М. Рубан, А. Ю. Зольнікова // Медична інформатика та інженерія. - 2012. - № I. - С.16-22.

5. Зольнікова А. Ю. Фактори ризику виникнення ятрогенних розривів сітківки в міні-інвазивному хірургічному лікуванні проліферативної діабетичної ретинопатії / А. Ю. Зольнікова, С. О. Риков, А. М. Рубан // Збірник наукових праць співробітників НМАПО імені П. Л. Шупика. - 2013. Вип.22, Кн. 1. - С. 285-291. 
6. Рубан А. М. Бімануальна міні-інвазивна техніка видалення заднього вітреошизису у пацієнтів на проліферативну діабетичну ретинопатію / А. М. Рубан // Зб. наук. праць співробіт. НМАПО імені П. Л. Шупика. - 2013. - Вип. 22, Кн. 4. - С. 90-98.

7. Родин С. С. Бевацизумаб (авастин) в комплексном хирургическом лечении больных с пролиферативной стадией диабетической ретинопатии / С. С. Родин, В. С. Аслано- ва // Український медичний альманах. - 2008. - Т. II, № 3. C. $126-128$.

8. Риков С. О. Значення інгра- та післяопераційних ускладнень у прогнозуванні виходу хірургічного лікування проліферативнї діабетичної ретинопатії / С. О. Риков, А. М. Рубан, А. Ю. Зольнікова // Медична інформатика та інженерія. - 2012. - Na 2. - С. 29. 